\title{
Identifikasi Karakteristik dan Faktor Pengaruh pada Berbagai Tipe Longsor
}

\author{
Identification of Characteristics and Influence Factors on Various Types of Landslides \\ Pranatasari Dyah Susanti*, Arina Miardini \\ Balai Penelitian dan Pengembangan Teknologi Pengelolaan Daerah Aliran Sungai, \\ Jl. A. Yani, Pabelan, Kartasura, Surakarta 57102, Indonesia \\ *Email: pranatasari_santi@yahoo.com
}

Tanggal submisi: 6 November 2018; Tanggal penerimaan: 5 April 2019

\begin{abstract}
ABSTRAK
Mitigasi bencana tanah longsor, sangat diperlukan pada wilayah-wilayah yang rentan terhadap bencana ini. Banjarnegara adalah salah satu kabupaten di Provinsi Jawa Tengah dengan potensi gerakan tanah yang tinggi, sehingga sangat rentan terhadap kejadian tanah longsor. Tujuan dari penelitian ini adalah mengetahui karakteristik dan faktor yang mempengaruhi tipe longsor di Kabupaten Banjarnegara. Pemilihan titik pengamatan pada penelitian ini berdasarkan hasil analisis kerentanan longsor di Kabupaten Banjarnegara. Identifikasi karakteristik longsor baik tipe maupun faktor yang mempengaruhinya dilakukan dengan metode survei dengan pengambilan sampel secara purposive random sampling melalui pertimbangan lokasi yang telah mengalami kejadian longsor serta tingkat kerentanan terhadap longsor. Survei dilakukan menggunakan Kartu Kendali Longsor (KKL) disusun berdasarkan parameter faktor penyebab longsor. Skoring dilakukan untuk mengetahui faktor penentu pada masing-masing titik sampel pengamatan secara kuantitatif, dengan skala 1 sampai 5. Hasil penelitian menunjukkan, terdapat tiga tipe longsor yang ditemukan pada lokasi penelitian, yaitu tipe rotasi, rayapan dan aliran. Faktor yang mempengaruhi tipe longsor rotasi di lokasi penelitian adalah: kemiringan lereng, kedalaman tanah, sesar dan infrastruktur, tipe rayapan dipengaruhi oleh faktor sesar, kemiringan lereng, panjang lereng, dan infrastruktur, sedangkan tipe aliran dipengaruhi oleh sesar dan infrastruktur. Nilai KKL tertinggi adalah 77 pada tipe longsor rotasi dan terendah 51 pada tipe longsor rayapan. Curah hujan juga menjadi faktor pemicu pada ketiga tipe longsor tersebut. Sangat disarankan untuk melakukan mitigasi secara teknis dengan memperhatikan kaidah konservasi tanah dan air serta adaptasi yang tinggi pada masyakat yang tinggal pada wilayah ini.
\end{abstract}

Kata kunci: Karakteristik; faktor dominan; tipe longsor

\begin{abstract}
Landslide disaster mitigation is necessary in areas vulnerable to this disaster. Banjarnegara is one of the regencies in Central Java Province with high ground movement potential, hence, it is prone to landslides. The aim of this study was to determine the characteristics and factors that influence the type of landslides in Banjarnegara District. The observation of the research was based on the results of landslide vulnerability analysis. Identification of the landslides characteristics, both in types and factors that influence them, are carried out by a survey method with a purposive random sampling technique by considering the locations that have experienced landslides, and the level of vulnerability to landslides. The survey was conducted using a landslide control card (KKL) which was compiled based on the factors that cause landslides. Scoring was done to determine the determinants of the landslide type quantitatively, on a scale of 1 to 5 . The results showed that there were three types of landslides found in the study location, namely rotational slide, creep slide and flows. Factors that influenced rotational slide in the study site were slope, soil depth, faults, and infrastructure, while for creep slide were faults, slope, length of slope, and infrastructure. In addition, flows were affected by faults and infrastructure. The highest KKL value was
\end{abstract}

DOI: http://doi.org/10.22146/agritech.41969

ISSN 0216-0455 (Print), ISSN 2527-3825 (Online) 
77 in the rotation landslide type and the lowest was 51 in the creep landslide type. Rainfall is also a trigger factor for the three types of landslides. It is highly recommended to do technical mitigation by observing the principles of soil and water conservation and high adaptation to the people living in this area.

Keywords: Characteristics; dominant factor; landslides types

\section{PENDAHULUAN}

Tanah longsor merupakan salah satu bencana alam yang mengakibatkan banyak korban jiwa serta kerugian dalam bidang perekonomian (Sideng dkk., 2018; Zhao dan Lu, 2018; Arsyad dkk., 2018). Menurut Rosita dkk. (2018) longsor adalah gerakan massa tanah atau batuan yang bergerak turun dan keluar lereng karena kestabilan tanah yang terganggu yang disebabkan oleh faktor pengontrol gangguan kestabilan lereng dan faktor pemicu. Kondisi geologi yang kompleks dengan gerakan tektonik yang multi periodik serta erosi yang tinggi dan dipicu oleh curah hujan akan menyebabkan peningkatan risiko longsor (Wen dkk., 2017).

Tian dkk. (2017) menyampaikan bahwa longsor memiliki tiga faktor longsor yaitu: (1) terrain data (elevation, slope angle, slope aspect, curvature, slope position, distance to drainage); (2) Geologic data (lithology) dan (3) Seismic data (seismic intensity, peak ground acceleration dan distance to causative). Sementara itu Arsyad, dkk. (2018) menyampaikan bahwa longsor disebabkan oleh gaya gravitasi pada lereng yang curam sebagai faktor utama dan faktor tambahan seperti curah hujan yang tinggi, penggunaan lahan yang kurang tepat, serta struktur geologi. Menurut Pamungkas dan Sartohadi (2017), longsor memiliki parameter intrinsik sebagai faktor utama dan faktor ekstrinsik yaitu faktor lain seperti fenomena alam yang dapat mempengaruhi faktor utama. Gea dan Pinem (2017) menambahkan bahwa ada 6 tipe longsor yang telah dikenal, yaitu rotasi, translasi, pergerakan blok, rayapan tanah, runtuhan batu serta aliran bahan rombakan yang dikenal sebagai tipe yang sangat mematikan.

Banjarnegara adalah wilayah di Jawa Tengah dengan frekuensi kejadian longsor yang tinggi dan menimbulkan korban jiwa. Menurut Arrisaldi dan Hidayat (2017) dan Hidayat (2018) Banjarnegera adalah wilayah dengan potensi gerakan tanah yang tinggi. Purwanti dkk. (2018) menyampaikan bahwa topografi Banjarnegara yang sangat bervariasi, membuat wilayah tersebut rawan terhadap bencana tanah longsor. Susanti dkk. (2017) juga menambahkan bahwa Kabupaten Banjarnegara memiliki serangkaian sejarah kejadian longsor. Selama 15 tahun terakhir (2003-2018) berdasarkan data BNPB (2018), terdapat
116 kali kejadian longsor, dengan korban meninggal dan hilang sebanyak 250 orang serta 13.755 orang harus mengungsi. Berdasarkan informasi dari BNPB (2018) tersebut, tercatat 2 kali kejadian dengan korban jiwa yang cukup besar yaitu pada tahun 2006 dengan korban jiwa sebanyak 120 orang dan pada tahun 2014 sebanyak 111 orang. Mengingat korban yang masih sangat tinggi, mitigasi longsor sangat diperlukan agar korban jiwa dapat dikurangi. Mitigasi longsor ini sangat diperlukan karena longsor memiliki dampak kerugian bagi manusia dan lingkungan dalam jangka panjang (Jen Chang dkk., 2018). Pham dkk. (2017) menambahkan bahwa faktor yang mempengaruhi tipe longsor penting untuk diketahui pada berbagai kondisi geologi yang berbeda. Tipe longsor dan faktor yang mempengaruhi sangat diperlukan sebagai dasar upaya mitigasi. Karena faktor yang berbeda akan menentukan upaya mitigasi yang berbeda pula, sehingga faktor-faktor utama pada berbagai tipe longsor sangat penting untuk diketahui. Penelitian ini bertujuan mengetahui karakteristik dan faktor yang mempengaruhi tipe longsor di Kabupaten Banjarnegara.

\section{METODE PENELITIAN}

\section{Bahan}

Bahan yang diperlukan dalam penelitian ini adalah Kartu Kendali Longsor (KKL) yaitu kuisioner yang digunakan selama penelitian. KKL digunakan sebagai bahan kuisioner untuk menentukan tipe longsor dan faktor-faktor yang mempengaruhinya.

\section{Alat}

Peralatan yang diperlukan dalam penelitian ini perlengkapan survei lapangan seperti: kertas label, pisau tanah, GPS, kompas, palu geologi, alat tulis dan dokumentasi.

\section{Lokasi Penelitian}

Lokasi penelitian adalah Kabupaten Banjarnegara yang berada Provinsi Jawa Tengah dan terletak diantara 7012'-7031' LS dan 109'29'-109045' BT. Banjarnegara memiliki luas $106.970,997$ ha yang terdiri dari 20 kecamatan. 


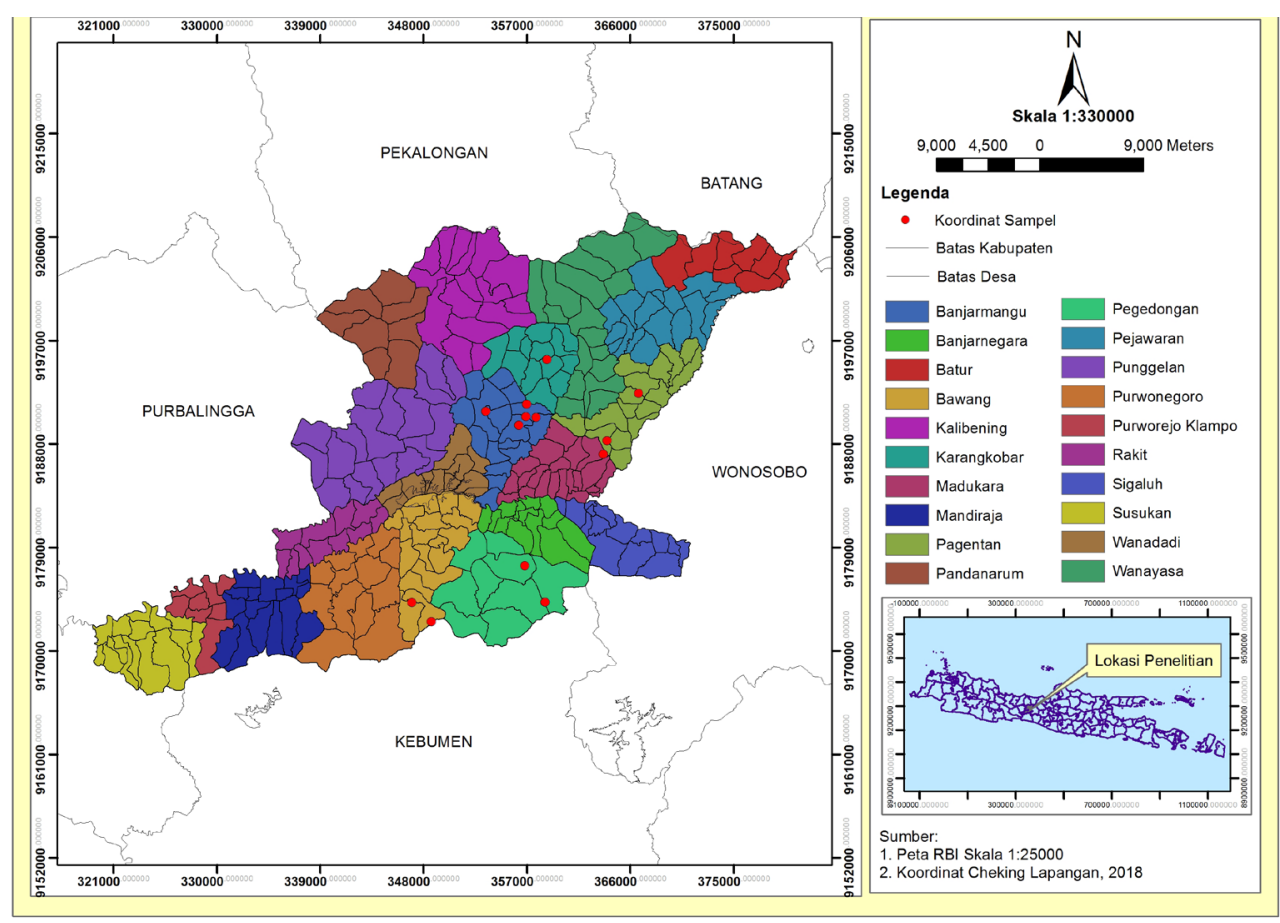

Gambar 1. Lokasi penelitian di Kabupaten Banjarnegara

\section{Metode}

Metode penelitian yang dilakukan dalam penelitian ini adalah survei pada lokasi terpilih. Lokasi sampel sebanyak 15 titik untuk mengetahui kondisi biofisik lahan serta tipe longsor dan faktor yang dominan pada tiap tipe longsor berdasarkan tabulasi KKL (Tabel 1). Lokasi pengamatan dipilih secara purposive random sampling berdasarkan lokasi-lokasi yang telah mengalami longsor dan merupakan hasil konsultasi dengan BPBD Kabupaten Banjarnegara. Lokasi tersebut juga memiliki potensi gerakan tanah menengah sampai tinggi berdasarkan data dari Pusat Vulkanologi dan Mitigasi Bencana Geologi (2015). Bahan survei berupa KKL disusun berdasarkan parameter faktor penyebab longsor dengan modifikasi dari berbagai sumber yaitu Paimin, Sukresno, dan Pramono (2009); Pusat Vulkanologi dan Mitigasi Bencana Geologi (2013, 2014); Liu dkk. (2013); dan Zhuang dkk. (2014). Faktor penyebab longsor tersebut, kemudian diskoring untuk mengetahui faktor penentu pada masing-masing titik sampel pengamatan secara kuantitatif. Faktor dengan nilai 4 (agak tinggi) dan 5 (tinggi) dianggap sebagai faktor yang paling berpengaruh.

Tabel 1. Kartu kendali longsor

\begin{tabular}{lllll}
\hline No & Faktor & Klasifikasi & Kategori & Skor \\
\hline 1 & Hujan harian kumulatif 3 hari & $<50$ & Rendah & 1 \\
& berurutan (mm/3 hari) & $50-99$ & Agak rendah & 2 \\
& & $100-199$ & Sedang & 3 \\
& & $200-300$ & Agak tinggi & 4 \\
& & $>300$ & Tinggi & 5 \\
\hline 2 & Aliran air permukaan & Tidak ada & Rendah & 1 \\
& & Sedikit & Agak rendah & 2 \\
& & Agak banyak & Sedang & 3 \\
& & Banyak & Agak tinggi & 4 \\
\hline 3 & Kontinyuitas air & Sangat banyak & Tinggi & 5 \\
& & Tidak ada & Rendah & 1 \\
\hline
\end{tabular}


P.A. Susanti dan A. Miardini /Agritech 39 (2) 2019 97-107

\begin{tabular}{|c|c|c|c|c|}
\hline No & Faktor & Klasifikasi & Kategori & Skor \\
\hline \multirow[t]{5}{*}{4} & Kualitas air & Bening & Rendah & 1 \\
\hline & & Agak bening & Agak rendah & 2 \\
\hline & & Agak keruh & Sedang & 3 \\
\hline & & Keruh & Agak tinggi & 4 \\
\hline & & Sangat keruh & Tinggi & 5 \\
\hline \multirow[t]{5}{*}{5} & Susut muka air & & Rendah & 1 \\
\hline & danau/bendungan & & Agak rendah & 2 \\
\hline & & & Sedang & 3 \\
\hline & & & Agak tinggi & 4 \\
\hline & & & Tinggi & 5 \\
\hline \multirow[t]{5}{*}{6} & Lereng lahan & $0-8 \%$ & Rendah & 1 \\
\hline & & $8-15 \%$ & Agak rendah & 2 \\
\hline & & $15-25 \%$ & Sedang & 3 \\
\hline & & $25-45 \%$ & Agak tinggi & 4 \\
\hline & & $>45 \%$ & Tinggi & 5 \\
\hline \multirow[t]{5}{*}{7} & Bentuk lereng & Cembung & Rendah & 1 \\
\hline & & Agak cembung & Agak rendah & 2 \\
\hline & & lurus & Sedang & 3 \\
\hline & & Agak cekung & Agak tinggi & 4 \\
\hline & & Cekung & Tinggi & 5 \\
\hline \multirow[t]{5}{*}{8} & Panjang lereng & $100-200$ & Rendah & 1 \\
\hline & & $200-300$ & Agak rendah & 2 \\
\hline & & $300-400$ & Sedang & 3 \\
\hline & & $400-500$ & Agak tinggi & 4 \\
\hline & & $>500$ & Tinggi & 5 \\
\hline \multirow[t]{5}{*}{9} & Arah lereng & Utara & Rendah & 1 \\
\hline & & Timur laut dan barat laut & Agak rendah & 2 \\
\hline & & Timur dan Barat & Sedang & 3 \\
\hline & & Tenggara dan Barat Daya & Agak tinggi & 4 \\
\hline & & Selatan & Tinggi & 5 \\
\hline \multirow[t]{5}{*}{10} & Gempa & $0-4$ SR & Rendah & 1 \\
\hline & & 4-5 SR & Agak rendah & 2 \\
\hline & & $5-6 \mathrm{SR}$ & Sedang & 3 \\
\hline & & 6-7 SR & Agak tinggi & 4 \\
\hline & & $>7 \mathrm{SR}$ & Tinggi & 5 \\
\hline \multirow[t]{5}{*}{11} & Material longsor & Bongkahan batuan & Rendah & 1 \\
\hline & & Bongkahan Tanah & Agak rendah & 2 \\
\hline & & Fragmen batuan/tanah & Sedang & 3 \\
\hline & & Partikel tanah & Agak tinggi & 4 \\
\hline & & Suspensi tanah (cairan) & Tinggi & 5 \\
\hline \multirow[t]{5}{*}{12} & Pengikisan/ erosi & $<15$ ton/ha/th & Rendah & 1 \\
\hline & & $15-60$ ton/ha/th & Agak rendah & 2 \\
\hline & & $60-180$ ton/ha/th & Sedang & 3 \\
\hline & & $180-480$ ton/ha/th & Agak tinggi & 4 \\
\hline & & $>480$ ton/ha/th & Tinggi & 5 \\
\hline \multirow[t]{5}{*}{13} & Warna tanah & Aquic & Rendah & 1 \\
\hline & & Coklat gelap & Agak rendah & 2 \\
\hline & & Coklat & Sedang & 3 \\
\hline & & Kuning & Agak tinggi & 4 \\
\hline & & Merah & Tinggi & 5 \\
\hline \multirow[t]{5}{*}{14} & Tekstur tanah & Sangat kasar $(\mathrm{S}, \mathrm{LS})$ & Tinggi & 5 \\
\hline & & Kasar (SL, L, SiL) & Agak tinggi & 4 \\
\hline & & Sedang (Si) & Sedang & 3 \\
\hline & & Halus (Scl, Sicl, Cl) & Agak rendah & 2 \\
\hline & & Sangat halus (Sic, Sc, C) & Rendah & 1 \\
\hline \multirow[t]{2}{*}{15} & Keberadaan sesar/patahan & Tidak ada & Rendah & 1 \\
\hline & Gawir & Ada & Tinggi & 5 \\
\hline \multirow[t]{3}{*}{16} & Struktur geologi & Tidak ada rekahan & Rendah & 1 \\
\hline & & Sedikit rekahan & Agak rendah & 2 \\
\hline & & Agak banyak rekahan & Sedang & 3 \\
\hline
\end{tabular}


P.A. Susanti dan A. Miardini /Agritech 39 (2) 2019 97-107

\begin{tabular}{|c|c|c|c|c|}
\hline No & Faktor & Klasifikasi & Kategori & Skor \\
\hline & & Banyak rekahan & Agak tinggi & 4 \\
\hline & & Sangat banyak rekahan & Tinggi & 5 \\
\hline \multirow[t]{5}{*}{17} & Kedalaman tanah (regolit) & $<1$ & Rendah & 1 \\
\hline & & $1-2$ & Agak rendah & 2 \\
\hline & & $2-3$ & Sedang & 3 \\
\hline & & 3-5 & Agak tinggi & 4 \\
\hline & & $>5$ & Tinggi & 5 \\
\hline \multirow[t]{5}{*}{18} & Penggunaa lahan & Air/rumput & Rendah & 1 \\
\hline & & Semak/belukar/terbuka & Agak rendah & 2 \\
\hline & & Hutan/perkebunan & Sedang & 3 \\
\hline & & Tegal/permukiman & Agak tinggi & 4 \\
\hline & & Sawah irigasi/ tadah hujan & Tinggi & 5 \\
\hline \multirow[t]{5}{*}{19} & Bangunan fisik & $0-25 \%$ & Rendah & 1 \\
\hline & & $25-45 \%$ & Agak rendah & 2 \\
\hline & & $45-65 \%$ & Sedang & 3 \\
\hline & & $65-85 \%$ & Agak tinggi & 4 \\
\hline & & $>85 \%$ & Tinggi & 5 \\
\hline \multirow[t]{2}{*}{20} & Infrastruktur (jika lereng <25) & Tidak ada jalan & Rendah & 1 \\
\hline & & Lereng terpotong jalan & Tinggi & 5 \\
\hline \multirow[t]{8}{*}{21} & Kepadatan pemukiman (org/ $/ \mathrm{km}^{2}$ ) & $<500$ & Rendah & 1 \\
\hline & & $500-1249$ & Rendah & 1 \\
\hline & & $1250-2499$ & Agak rendah & 2 \\
\hline & & $2500-3999$ & Agak rendah & 2 \\
\hline & & 4000-5999 & Sedang & 3 \\
\hline & & $6000-7499$ & Agak tinggi & 4 \\
\hline & & $7500-8499$ & Agak tinggi & 4 \\
\hline & & $>8500$ & Tinggi & 5 \\
\hline \multirow[t]{5}{*}{22} & Daerah pembuangan sampah & $>25 \mathrm{~m}$ & Rendah & 1 \\
\hline & & $20-25 \mathrm{~m}$ & Agak rendah & 2 \\
\hline & & $15-20 \mathrm{~m}$ & Sedang & 3 \\
\hline & & $10-15 \mathrm{~m}$ & Agak tinggi & 4 \\
\hline & & $<10 \mathrm{~m}$ & Tinggi & 5 \\
\hline \multirow[t]{6}{*}{23} & Laju kecepatan gerakan tanah & $16 \mathrm{~mm} / \mathrm{th}$ & Sangat lambat & 1 \\
\hline & & $1,6 \mathrm{~m} / \mathrm{th}$ & Lambat & 1 \\
\hline & & $13 \mathrm{~m} / \mathrm{bln}$ & Sedang & 2 \\
\hline & & $1,8 \mathrm{~m} / \mathrm{jam}$ & Cepat & 3 \\
\hline & & $3 \mathrm{~m} /$ menit & Sangat cepat & 4 \\
\hline & & $5 \mathrm{~m} /$ detik & Ekstrim sangat cepat & 5 \\
\hline \multirow[t]{5}{*}{24} & Kondisi kerapatan vegetasi & Sangat rapat $(>80 \%)$ & Rendah & 1 \\
\hline & & Rapat $(60-80 \%)$ & Agak rendah & 2 \\
\hline & & Sedang $(40-60 \%)$ & Sedang & 3 \\
\hline & & Jarang $(20-40 \%)$ & Agak tinggi & 4 \\
\hline & & Sangat jarang $(<20 \%)$ & Tinggi & 5 \\
\hline \multirow[t]{2}{*}{25} & Kondisi distribusi akar vegetasi & Horizontal & Rendah & 1 \\
\hline & & Vertikal & Tinggi & 5 \\
\hline \multirow[t]{5}{*}{26} & Ordo tanah & Entisol, Histosol & Rendah & 1 \\
\hline & & Oxisol & Agak rendah & 2 \\
\hline & & Spodosol, Andisol & Sedang & 3 \\
\hline & & Alfisol, Inceptisol, Mollisol & Agak tinggi & 4 \\
\hline & & Ultisol, Vertisol & Tinggi & 5 \\
\hline \multirow[t]{5}{*}{27} & Kondisi geologi & Dataran alluvial & Rendah & 1 \\
\hline & & Kapur & Agak rendah & 2 \\
\hline & & Granit & Sedang & 3 \\
\hline & & Sedimen & Agak tinggi & 4 \\
\hline & & Basal-Claysale & Tinggi & 5 \\
\hline
\end{tabular}

Sumber: Modifikasi Paimin, Sukresno, dan Pramono (2009); Pusat Vulkanologi dan Mitigasi Bencana Geologi (2013, 2014); Liu dkk.

(2013); dan Zhuang, Iqbal, Peng, Liu (2014) 


\section{HASIL DAN PEMBAHASAN}

\section{Kondisi Umum dan Tingkat Kerentanan Longsor}

Gerakan tanah dapat memicu terjadinya longsor. Berdasarkan informasi dari Tingkat Pusat Vulkanologi dan Mitigasi Bencana Geologi (2015), wilayah Kabupaten Banjarnegara memiliki tingkat potensi gerakan tanah pada kategori menengah-tinggi. Berikut ini hasil analisis tingkat kerentanan longsor di wilayah Banjarnegara (Tabel 2).

Berdasarkan Tabel 2 dapat diketahui bahwa kerentanan longsor di Kabupaten Banjarnegara ini didominasi pada kelas tinggi-sangat tinggi seluas 50,8\%. Dari besaran persentase tersebut, sebesar 26,06\% memiliki kerentanan sangat tinggi, kerentanan tinggi sebesar $24,73 \%$, kerentanan sedang 25,06\%, kerentanan rendah $15,23 \%$ dan kerentanan sangat rendah sebesar $8,86 \%$. Lima kecamatan dengan luasan tertinggi dalam kelas kerentanan sangat tinggi diantaranya Kecamatan Wanayasa, Kalibening, Pejawaran, Pagedongan dan Karangkobar.

Secara umum terdapat $63,8 \%$ atau sekitar $68.284,9$ ha wilayah Banjarnegara yang terdampak sesar dan memiliki kelerangan $24-45 \%$ sebesar $29,4 \%$ dari total wilayah dengan kelerengan terjal yaitu $>45 \%$ sebesar $15,5 \%$ atau sekitar $16.532,8$ ha (Harjadi dkk, 2016). Kondisi tersebut, merupakan potensi timbulnya gerakan tanah dan kerawanan terhadap longsor. Seperti disampaikan oleh Khosiah dan Ariani (2017) bahwa tanah longsor dapat terjadi karena gerakan tanah yang berasal dari pergerakan batuan ataupun massa tanah. Handayani dan Singarimbun (2016) juga menambahkan bahwa kejadian longsor bukan hanya disebabkan oleh faktor iklim dan kondisi tanah, tetapi kemiringan lereng, bentuk muka bumi, sesar, curah hujan dan penutupan lahan juga menjadi faktor penyebab longsor.

\section{Tipe Longsor}

Karakteristik longsor yang diamati dalam penelitian ini adalah tipe longsor dan faktor yang mempengaruhinya. Hasil identifikasi karakteristik longsor pada lokasi penelitian disajikan pada Tabel 3.

Berdasarkan hasil survei di lapangan, dapat diketahui bahwa di Kabupaten Banjarnegara terdapat 3 tipe longsor, yaitu: rotasi, rayapan dan aliran. Tipe longsor rotasi berada pada lokasi: (1). Clapar, Clapar, Madukara; (2). Jemblung, Sampang, Karangkobar; (3). Gunungraja, Sijeruk, Banjarmangu, dan (4). Gender, Pesangkalan, Pagedongan.

Tipe longsor rayapan terjadi pada lokasi: (1). Bawang, Aribaya, Pagentan; (2). Derikan, Kalitlaga, Pagentan; (3). Serang Turi, Sijeruk, Banjarmangu; (4). Genggong, Kaliunjar, Banjarmangu; (5). Simbang, Sipedang, Banjarmangu; (6). Wanajeneng, Pagedongan dan (7). Nangka sepet, Masaran, Bawang; (8). Kebondalem, Bawang, sedangkan tipe aliran pada lokasi penelitian ditemukan pada satu lokasi di Karangsengon, Sigeblug, Banjarmangu.

Tabel 2. Tingkat kerentanan di tiap kecamatan

\begin{tabular}{|c|c|c|c|c|c|c|}
\hline \multirow[b]{2}{*}{ No } & \multirow{2}{*}{ Kecamatan } & \multicolumn{5}{|c|}{ Kategori/Luas (ha) } \\
\hline & & Sangat rendah & Rendah & Sedang & Tinggi & Sangat tinggi \\
\hline 1 & Banjarmangu & 453,9 & 749,1 & $1.503,8$ & $1.312,4$ & 970,6 \\
\hline 2 & Banjarnegara & 12,3 & 801,8 & 831,0 & 737,6 & $1.060,7$ \\
\hline 3 & Batur & 70,4 & 261,8 & 952,0 & $1.218,1$ & $1.398,7$ \\
\hline 4 & Bawang & $1.736,7$ & $1.524,3$ & $1.150,2$ & 708,7 & 529,6 \\
\hline 5 & Kalibening & 0 & 778,6 & $1.180,2$ & $2.408,5$ & $4.192,5$ \\
\hline 6 & Karangkobar & 0 & 20,7 & 767,7 & $1.269,4$ & $1.879,0$ \\
\hline 7 & Madukara & 486,4 & 762,7 & $1.291,3$ & $1.100,1$ & 550,0 \\
\hline 8 & Mandiraja & 7,3 & $1.969,2$ & $1.429,5$ & 801,9 & 855,1 \\
\hline 9 & Pagentan & 31,5 & 232,0 & $1.783,5$ & $1.650,6$ & $1.086,0$ \\
\hline 10 & Pandanarum & 43,2 & 202,9 & $1.320,7$ & $2.017,2$ & $1.829,9$ \\
\hline 11 & Pegedongan & 33,6 & 284,1 & $1.795,2$ & $3.463,7$ & $1.879,2$ \\
\hline 12 & Pejawaran & 10,4 & 150,4 & $1.239,6$ & $1.557,1$ & $2.865,2$ \\
\hline 13 & Punggelan & $1.393,6$ & $2.690,2$ & $4.796,0$ & $1.474,4$ & 229,4 \\
\hline 14 & Purwonegoro & 581,1 & $1.922,8$ & $2.000,2$ & $2.292,9$ & 668,3 \\
\hline 15 & Purworejo Klampo & 902,0 & 604,8 & 213,9 & 97,4 & 333,7 \\
\hline 16 & Rakit & 920,4 & $1.512,9$ & 441,4 & 128,3 & 2,4 \\
\hline 17 & Sigaluh & 134,3 & 330,9 & $1.278,0$ & $1.186,9$ & $1.056,8$ \\
\hline 18 & Susukan & 985,5 & $1.040,4$ & 615,2 & 605,5 & $1.587,1$ \\
\hline 19 & Wanadadi & $1.672,6$ & 442,4 & 494,4 & 176,0 & 5,5 \\
\hline 20 & Wanayasa & 4,0 & 68,0 & $1.726,6$ & $2.241,7$ & $4.903,6$ \\
\hline
\end{tabular}

Sumber: Harjadi dkk. (2016) 
Tabel 3. Identifikasi karakteristik dan faktor yang mempengaruhi longsor pada berbagai tipe longsor

\begin{tabular}{|c|c|c|c|c|c|c|}
\hline \multirow[b]{2}{*}{ No. } & \multirow[b]{2}{*}{ Lokasi pengamatan } & \multirow{2}{*}{$\begin{array}{l}\text { Nilai } \\
\text { KKL }\end{array}$} & \multicolumn{4}{|c|}{ Karakteristik longsor } \\
\hline & & & $\begin{array}{l}\text { Koordinat } \\
(X, Y)\end{array}$ & $\begin{array}{l}\text { Ordo } \\
\text { tanah }\end{array}$ & $\begin{array}{l}\text { Jenis } \\
\text { longsor }\end{array}$ & Faktor dominan \\
\hline 1 & Clapar, Clapar, Madukara & 77 & $\begin{array}{l}363627 \\
9187092\end{array}$ & Ultisol & Rotasi & $\begin{array}{l}\text { panjang lereng, sesar, kedalaman } \\
\text { regolit tanah, infrastruktur }\end{array}$ \\
\hline 2 & $\begin{array}{l}\text { Bawang, Aribaya, } \\
\text { Pagentan }\end{array}$ & 58 & $\begin{array}{l}346978 \\
9174200\end{array}$ & Inceptiso & Rayapan & sesar \\
\hline 3 & $\begin{array}{l}\text { Derikan, Kalitlaga, } \\
\text { Pagentan }\end{array}$ & 65 & $\begin{array}{l}366698 \\
9192397\end{array}$ & Ultisol & Rayapan & $\begin{array}{l}\text { kemiringan lereng, sesar, } \\
\text { infrastruktur }\end{array}$ \\
\hline 4 & $\begin{array}{l}\text { Jemblung, Sampang, } \\
\text { Karangkobar }\end{array}$ & 72 & $\begin{array}{l}358724 \\
9195322\end{array}$ & Ultisol & Rotasi & $\begin{array}{l}\text { kemiringan lereng, bentuk lereng, } \\
\text { sesar, geologi, kedalaman regolit } \\
\text { tanah, infrastruktur }\end{array}$ \\
\hline 5 & $\begin{array}{l}\text { Gunungraja, Sijeruk, } \\
\text { Banjarmangu }\end{array}$ & 63 & $\begin{array}{l}357057 \\
9190291\end{array}$ & Inceptisol & Rotasi & kemiringan lereng, bentuk lereng, \\
\hline 6 & $\begin{array}{l}\text { Serang Turi, Sijeruk, } \\
\text { Banjarmangu }\end{array}$ & 69 & $\begin{array}{l}357058 \\
9190317\end{array}$ & Inceptisol & Rayapan & $\begin{array}{l}\text { regollt tanah, infrastruktur } \\
\text { sesar, infrastruktur }\end{array}$ \\
\hline 7 & $\begin{array}{l}\text { Genggong, Kaliunjar, } \\
\text { Banjarmangu }\end{array}$ & 58 & $\begin{array}{l}357801 \\
9190307\end{array}$ & Inceptisol & Rayapan & $\begin{array}{l}\text { kemiringan lereng, panjang } \\
\text { lereng, sesar, kedalaman regolit } \\
\text { tanah, infrastruktur }\end{array}$ \\
\hline 8 & $\begin{array}{l}\text { Simbang, Sipedang, } \\
\text { Banjarmangu }\end{array}$ & 64 & $\begin{array}{l}357058 \\
9190491\end{array}$ & Inceptisol & Rayapan & $\begin{array}{l}\text { panjang lereng, sesar, } \\
\text { infrastruktur }\end{array}$ \\
\hline 9 & $\begin{array}{l}\text { Karangsengon, Sigeblug, } \\
\text { Banjarmangu }\end{array}$ & 58 & $\begin{array}{l}353393 \\
9190817\end{array}$ & Inceptisol & Aliran & sesar, infrastruktur \\
\hline 10 & $\begin{array}{l}\text { Gender, pesangkalan, } \\
\text { pagedongan }\end{array}$ & 59 & $\begin{array}{l}358581 \\
9174209\end{array}$ & Entisol & Rotasi & $\begin{array}{l}\text { kemiringan lereng, sesar, } \\
\text { infrastruktur, }\end{array}$ \\
\hline 11 & $\begin{array}{l}\text { Gender, Pesangkalan, } \\
\text { Pagedongan }\end{array}$ & 61 & $\begin{array}{l}358569 \\
9174217\end{array}$ & Inceptisol & Rotasi & $\begin{array}{l}\text { kemiringan lereng, arah lereng, } \\
\text { sesar, kedalaman regolit tanah, } \\
\text { infrastruktur }\end{array}$ \\
\hline 12 & Wanajeneng, pagedongan & 55 & $\begin{array}{l}356797 \\
9177385\end{array}$ & Inceptisol & Rayapan & sesar \\
\hline 13 & $\begin{array}{l}\text { Nangka sepet, Masaran, } \\
\text { Bawang }\end{array}$ & 62 & $\begin{array}{l}350382 \\
918000\end{array}$ & Ultisol & Rayapan & $\begin{array}{l}\text { kemiringan lereng, bentuk lereng, } \\
\text { sesar, infrastruktur }\end{array}$ \\
\hline 14 & Kebondalem, Bawang & 51 & $\begin{array}{l}348653 \\
9172510\end{array}$ & Inceptisol & Rayapan & $\begin{array}{l}\text { kemiringan lereng, bentuk lereng, } \\
\text { panjang lereng, kedalaman } \\
\text { regolit tanah }\end{array}$ \\
\hline 15 & Kemiri, Aribaya, Pagentan & 67 & $\begin{array}{l}363955 \\
9188282\end{array}$ & Inceptisol & Rayapan & $\begin{array}{l}\text { kemiringan lereng, bentuk lereng, } \\
\text { panjang lereng, sesar, kedalaman } \\
\text { regolit tanah }\end{array}$ \\
\hline
\end{tabular}

Sumber: Analisis data, 2018

Hasil pengamatan di lapangan pada lahan dengan tipe rotasi dapat diketahui kondisi topografi pada tipe tersebut didominasi oleh perbukitan dengan kemiringan lereng yang terjal pada daerah mahkota hingga daerah tengah longsoran dengan ketebalan tanah dalam mencapai $20-30 \mathrm{~m}$. Kelerengan akan semakin landai pada daerah tengah sampai kaki longsoran. Morfologi di bagian mahkota longsor terdiri dari material hasil pengendapan berupa bongkahan batuan yang labil dan mudah lepas akibat pelapukan. Morfologi daerah penelitian yang miring menyebabkan gaya vertikal yang menarik material longsor ke arah bawah semakin tinggi, sehingga menimbulkan longsoran dengan karakteristik cekungan dan cenderung memiliki volume massa tanah yang besar. 
Pada tipe longsor rayapan juga dapat diketahui dari hasil survei di lapangan yang ditandai dengan adanya pohon-pohon dan tiang listrik yang sudah miring akibat gerakan tanah secara berlahan. Selain itu banyak dijumpai retakan-retakan pada dinding rumah serta posisi jendela dan pintu rumah yang mulai bergeser dari tempatnya. Hal ini menunjukkan bahwa tipe longsor yang terjadi pada wilayah-wilayah tersebut adalah rayapan. Tipe aliran pada lokasi penelitian ditemukan pada satu lokasi di Karangsengon, Sigeblug, Banjarmangu. Adanya sisa-sisa alur akibat aliran air dari puncak bukit atau lereng diduga bahwa pada lokasi tersebut telah terjadi longsor tipe aliran.

Menurut Permen PU No. 22/PRT/M/ 2007 tentang Pedoman Penataan Ruang Kawasan Rawan Bencana Longsor, rayapan tanah merupakan jenis longsor butiran baik kasar maupun halus, tidak mudah dikenali, namun dapat dilihat dari timbulnya kemiringan pada tiang listrik, telepon, pagar ataupun pohon. Dalam Permen PU tersebut juga dijelaskan bahwa longsor dengan tipe rotasi merupakan pergerakan massa tanah dan batuan pada bidang gelincir dengan bentuk cekung, sedangkan tipe aliran merupkan tipe longsor yang disebabkan oleh air, dengan kecepatan aliran tergantung pada kemiringan, volume air, tekanan air dan jenis material yang dibawanya.

Tipe longsor rayapan tersebar pada kemiringan agak curam (8-15\%) banyak dijumpai pada kebun campuran dan permukiman. Mekanisme longsor rayapan melaui perpindahan material batuan atau tanah ke arah kaki lereng memiliki pergerakan yang lambat, sehingga cukup waktu dalam mempersiapkan mitigasi sebelum menimbulkan kerusakan lebih parah. Hal senada juga dapat dilihat dalam penjelasan Pusat Vulkanologi dan Mitigasi Bencana Geologi (2013), bahwa tipe tanah rayapan merupakan tipe longsor dengan pergerakan yang lambat, sedangkan tipe longsor aliran merupakan tipe longsor yang dapat mencapai ratusan meter dengan korban yang ditimbulkan cukup banyak. Hidayat (2018) menambahkan bahwa tipe longsor rotasi sering terjadi di Indonesia pada wilayah-wilayah yang memiliki kontak antara batuan dasar dengan zona pelapukan.

\section{Identifikasi Faktor}

Berdasarkan tipe longsor yang diketahui di lapangan, terdapat beberapa faktor dominan yang ditemukan pada masing-masing tipe longsor (Tabel 3). Faktor yang kemungkinan paling berpengaruh pada tipe longsor rotasi di lokasi penelitian adalah: kemiringan lereng, kedalaman tanah, sesar dan infrastruktur. Tipe rayapan kemungkinan dipengaruhi oleh faktor sesar, kemiringan lereng, panjang lereng dan infrastruktur, sedangkan tipe aliran kemungkinan dipengaruhi oleh sesar dan infrastruktur.
Pada penelitian ini, dapat diketahui bahwa dari ketiga tipe longsor yang ditemukan pada wilayah survei terdapat beberapa faktor dominan kemungkinan penyebab longsor yaitu: lereng, sesar, kedalaman tanah dan infrastruktur, serta curah hujan sebagai faktor pemicu. Lereng yang curam cenderung berpotensi terhadap longsor, terutama dengan kondisi lereng yang tidak stabil. Hasil penelitian Fauzan dkk. (2018) menyebutkan bahwa stabilitas tanah berbanding terbalik dengan kemiringan lereng, yaitu semakin besar nilai kemiringan suatu lereng maka nilai stabilitas tanah akan semakin kecil. Kondisi topografi pada wilayah penelitian sangat bervariasi, dan didominasi oleh perbukitan. Hal tersebut menyebabkan banyaknya lereng-lereng yang curam sampai terjal.

Lereng yang semakin curam, akan meningkatkan potensi longsor (Buchori dan Susilo, 2012). Hal ini seperti disampaikan oleh Hidayat (2018) bahwa longsor sering ditemukan pada permukaan yang miring dan pengaruh gravitasi. Hasil penelitian Pamungkas dan Sartohadi (2017) juga menyebutkan bahwa geometri lereng akan berpengaruh terhadap longsor, dan panjang lereng berbanding terbalik dengan kemiringan lereng.

Penggunaan lahan pada lereng yang curam juga berpengaruh pada kestabilan lereng. Penggunaan lahan di wilayah penelitian didominasi oleh perkebunan, permukiman dan sawah. Berdasarkan hasil penelitian Ramadhani dan Idajati (2017) disampaikan bahwa penggunaan lahan merupakan salah satu faktor penyebab longsor. Hal ini sering ditemukan pada tipe longsor rotasi. Pada tipe longsor yang sama di Kabupaten Kuningan Jawa Barat, diketahui bahwa faktor utama yang memicu kejadian longsor pada tipe ini adalah kemiringan lereng, sesar dan infrastruktur (Harjadi dkk., 2015). Pada tipe ini massa tanah akan bergerak pada bidang gelincir yang berbentuk cekung.

Selain lereng, sesar merupakan faktor utama yang menjadi penyebab longsor pada ketiga tipe longsor. Sesar adalah retakan yang berada pada batuan bumi yang disebabkan oleh pergeseran baik vertikal maupun horizontal sehingga akan mengakibatkan pergerakan yang relatif pada blok batuan yang berada disekitarnya (Kurniati, 2017). Hal ini akan memperbesar potensi longsor (Nasiah dan Invanni, 2014). Hasil penelitian Kumajas (2006) menunjukkan bahwa keberadaan sesar akan mempengaruhi kestabilan batuan, sehingga akan berpengaruh pada kerentanan longsor. Wen $d k k$. (2017) juga menambahkan bahwa jarak dari bidang patahan atau sesar merupakan salah satu penilaian tingkat kerentanan longsor.

Faktor selanjutnya sebagai faktor utama yang dimungkinkan berperan sebagai pemicu longsor pada berbagai tipe di Banjarnegara adalah kedalaman tanah. 
Kedalaman tanah ini berhubungan dengan jenis tanah. Salah satu kondisi geologi yang berpengaruh terhadap longsor adalah jenis tanah. Jenis tanah merupakan salah satu faktor penyebab longsor (Setiadi, 2013; Ramadhani dan Idajati, 2017). Hasibuan dan Rahayu (2017) menambahkan bahwa jenis tanah adalah faktor internal penyebab longsor, yang dapat diamati dari tingkat kepekaan terhadap erosi untuk menentukan tingkat longsor. Hasil penelitian ini menjukkan bahwa sebagaian besar jenis tanah yang ditemukan adalah Ultisol dan Inseptisol dengan kedalaman lebih dari $3 \mathrm{~m}$. Menurut Chaeril, Tjoneng dan Saida (2018), jenis tanah Inceptisol adalah jenis tanah yang agak peka sedangkan Ultisol masuk kategori peka terhadap erosi yang dapat mengakibatkan longsor.

Faktor yang dominan pada tipe longsor di Banjarnegara selanjutnya adalah infrastruktur. Infrastruktur dapat berpengaruh terhadap longsor karena infrastuktur yang terbangun pada wilayah yang rentan terhadap longsor merupakan beban bagi lereng. Infrastruktur yang ditemui pada lokasi penelitian diantaranya adalah permukiman dan empang yang terbangun pada lereng yang terjal, serta bangunan jalan yang memotong lereng. Infrastruktur tersebut, akan menjadi beban lereng yang akan mempengaruhi tingkat kestabilan lereng. Menurut Paimin, Pramono, Purwanto dan Indrawati (2012), infrastruktur merupakan salah satu faktor penyebab longsor dari aspek manajemen, dengan kategori sangat tinggi terhadap kerentanan longsor apabila ditemukan pembangunan infrastruktur jalan yang memotong lereng. Pemotongan tebing untuk alih fungsi lahan seperti pembangunan permukiman maupun sarana infrastruktur jalan tanpa memperhatikan prinsip konservasi, maka akan menimbulkan longsor (Abrauw, 2017; Khosiah dan Ariani, 2017). Chaeril dkk. (2018) juga menambahkan bahwa pada wilayah yang rawan terhadap longsor, pembangunan infrastruktur dalam bidang pertanian, akan menyebabkan perubahan komposisi tanah dan meningkatkan gerakan tanah yang dapat memicu longsor.

Selain faktor dominan pada masing-masing tipe longsor, terdapat pula faktor pemicu yang sangat penting untuk diperhatikan, yaitu curah hujan (Hidayat, 2018). Hal ini juga diperkuat dalam Harjadi dkk. (2016), bahwa terdapat beberapa faktor penyebab longsor diantaranya faktor mayor (lereng, sesar, tekstur, kedalaman regolith, dan geologi); faktor minor (bentuk lereng, agregasi, permeabilitas, drainase dan struktur) serta faktor pemicu yaitu alam (curah hujan dan gerakan tanah) dan buatan (pemotongan tebing tegak dan beban lereng). Berdasarkan hasil identifikasi di lapangan, diketahui bahwa curah hujan menjadi faktor pemicu yang sangat berpengaruh pada kejadian longsor. Menurut Pamin dkk.
(2012) curah hujan >300 mm selama 3 hari berturutturut pada daerah yang rawan terhadap longsor, masuk dalam kategori kerentanan tinggi terhadap kejadian longsor. Hidayat (2018) menambahkan bahwa air hujan selain menyebabkan peningkatan massa tanah juga melemahkan ikatan partikel tanah, sehingga dapat memicu longsor.

\section{KESIMPULAN}

Wilayah Banjarnegara memiliki kerentanan yang tinggi terhadap kejadian longsor. Terdapat 3 tipe longsor yang ditemukan dalam penelitian ini yaitu rotasi, rayapan dan aliran. Kemungkinan faktor dominan pada tipe longsor rotasi adalah kemiringan lereng, kedalaman tanah, sesar dan infrastruktur. Tipe rayapan kemungkinan dipengaruhi oleh faktor sesar, kemiringan lereng, panjang lereng dan infrastruktur, sedangkan tipe aliran kemungkinan dipengaruhi oleh sesar dan infrastruktur.

Mengingat tingkat kejadian dan korban yang ditimbulkan masih sangat tinggi pada wilayah Banjarnegara, maka diperlukan upaya preventif sebagai salah satu teknik mitigasi terhadap bencana tanah longsor pada wilayah ini. Salah satu hal yang harus dipertimbangkan adalah peningkatan kesadaran masyarakat terkait adaptasi pada bencana ini. Kesadaran tentang kondisi morfologis dan topografis pada daerah dimana mereka tinggal menjadi sangat penting, karena faktor inilah yang menjadi faktor-faktor dominan penyebab longsor.

Penerapan kaidah-kaidah konservasi tanah dan air menjadi bagian yang tidak dapat dikesampingkan agar dampak dari faktor-faktor dominan penyebab longsor dapat diminimalisir. Beberapa hal yang dapat dilakukan diantaranya: menutup rekahan-rekahan tanah, memperhatikan dan merancang saluran pembuangan air dengan benar, serta tidak menambah beban lereng dengan pembangunan infrastruktur yang mengakibatkan kestabilan lereng terganggu. Curah hujan sebagai faktor pemicu longsor juga harus diperhatikan oleh masyarakat yang tinggal pada kawasan ini, sehingga dapat menambah kewaspadaan dan kesiap-siagaan terhadap bencana tanah longsor saat menjelang musim hujan tiba.

\section{UCAPAN TERIMA KASIH}

Ucapan terima kasih terutama ditujukan kepada tim peneliti dan teknisi BPPTPDAS Solo yang telah membantu dalam pelaksanaan penelitian di lapangan. 


\section{KONFLIK KEPENTINGAN}

Penulis menyatakan bahwa artikel ini asli, belum pernah dipublikasikan, dan bebas dari konflik kepentingan.

\section{DAFTAR PUSTAKA}

Abrauw. R.D. Wilayah rawan longsor di Kota Jayapura. Jurnal Geografi Lingkungan Tropik, 1 (1), 14-28. DOI: http:// dx.doi.org/10.7454/jglitrop.v1i1.4

Arrisaldi. T. dan Hidayat. R. Kajian Pemanfaatan Wilayah Rawan Longsor Di Kecamatan Karangkobar, Kabupaten Banjarnegara Berdasarkan Peraturan Menteri Pekerjaan Umum No.22/Prt/M/2007 Dengan Modifikasi. Prosiding Seminar Nasional Geografi UMS 2017. Surakarta, 22 Mei 2017: 159-170.

Arsyad. U., Barkey. R., Wahyuni, dan Matandung. K. K. (2018). Karakteristik Tanah Longsor di Daerah Aliran Sungai Tangka. Jurnal Hutan dan Masyarakat. Vol. 10 (1), 203214. DOI: http://dx.doi.org/10.24259/jhm.v0i0.3978

BNPB. (2018). Data dan Informasi Bencana. http://bnpb. cloud/dibi/laporan4. Diakses pada tanggal 3 September 2018.

BNPB. (2018). Data dan Informasi Bencana. http://bnpb. cloud/dibi/tabel3a. Diakses pada tanggal 3 September 2018.

Buchori. I. dan susilo. J. (2012). Model Keruangan untuk Identifikasi Kawasan Rawan Longsor. Tata Loka 14 (4) November: 282-294.

Chaeril, Tjoneng. A., dan Saida. (2018). Analisis Kerawanan Longsor Berbasis Spasial Di Kawasan Taman Nasional Bantimurung Bulusaraung. Jurnal Agrotek 2 (1) Maret: 54-68.

Fauzan. M. E., Damayanti. A., dan Saraswati. R. (2018). Wilayah Potensi Bencana Tanah Longsor Dengan Metode Sinmap di Daerah Aliran Ci Manuk Hulu, Kabupaten Garut, Jawa Barat. Prosiding Seminar Nasional Geotik 2018. Surakarta 28 April 2018.

Gea. N. M. S. dan Pinem. K. (2017). Agihan Daerah Rawan Longsor Lahan di Sebagian Wilayah Kabupaten Karo Provinsi Sumatera Utara. Jurnal Pendidikan Ilmu-IImu Sosial 9 (1), 42-56. DOI: https://doi.org/10.24114/ jupiis.v9i1.6460

Handayani. L. dan Singarimbun. A. (2016). Pemetaan Daerah Rawan Longsor Di Sekitar Daerah Prospek Panas Bumi Provinsi Jawa Barat. Jop, 2 (1), November: 17 - 22.

Harjadi. B., Donie. S., Jariyah. N.A., Susanti. P. D., Siswo, Sugianto. A. (2015). Teknik Mitigasi Bencana Tanah Longsor di Pulau Jawa. Laporan Hasil Penelitian. BPPTPDAS Solo. Unpublish.
Harjadi. B., Donie. S., Jariyah. N.A., Susanti. P. D., Miardini. A., Siswo, Sugianto. A. (2016). Teknik Mitigasi Bencana (Banjir dan Tanah Longsor) di Pulau Jawa. Laporan Hasil Penelitian. BPPTPDAS Solo. Unpublish.

Hasibuan. H. C. dan Rahayu. S. (2017). Kesesuaian Lahan Permukiman Pada Kawasan Rawan Bencana Tanah Longsor Di Kabupaten Temanggung. Jurnal teknik PWK 6(4): 242-256.

Hidayat. R. (2018). Analisis Stabilitas Lereng Pada Longsor Desa Caok, Purworejo, Jawa Tengah. Jurnal Sumber Daya Air 14 (1), Mei: $63 \square 74$.

Hidayat. R. 2018. Kondisi Geologi Teknik Daerah Rawan Longsor Kecamatan Karangkobar, Banjarnegara. Prosiding Seminar Nasional Teknik Sipil UMS 2018, 95104.

Jen Chang. K., Chang Chan. Y., Fei Chen. R., dan Chung Hsieh. Y. (2018). Geomorphological evolution of landslides near an active normal fault in northern Taiwan, as revealed by lidar and unmanned aircraft system data. Nat. Hazards Earth Syst. Sci., 18, 709-727, 2018 https://doi. org/10.5194/nhess-18-709-2018.

Khosiah dan Ariani. A. (2017). Tingkat Kerawanan Tanah Longsor Di Dusun Landungan Desa Guntur Macan Kecamatan Gunungsari Kabupaten Lombok Barat. Jime 3(1), 195-200.

Kumajas. M. (2006). Inventarisasi Dan Pemetaan Rawan Longsor Kota Manado - Sulawesi Utara. Forum Geografi 20(2), 190 - 197.

Kurniati. A. (2017). Aplikasi Mekanisme Fokus Dalam Identifikasi Sesar Di Sulawesi Bagian Selatan. Fakultas MIPA. Universitas Hasanudin. Makasar. Skripsi. 83 p.

Liu, C., Li, W., Wu, H., Lu, P., Sang, K., Sun, W., Chen, W., Hong, Y., Li, R. (2013). Susceptibility evaluation ang mapping of China's landslides based on multi-source data. Nat Hazards (69), 1477-1495. https://doi.org/10.1007/ s11069-013-0759-y

Nasiah dan Invanni. I. (2014). Identifikasi Daerah Rawan Bencana Longsor Lahan Sebagai Upaya Penanggulangan Bencana di Kabupaten Sinjai. Jurnal Sainsmat III (2), 109-121. https://doi. org/10.35580/sainsmat3211012014

Ramadhani. N. I. dan Idajati. H. (2017). Identifikasi Tingkat Bahaya Bencana Longsor, Studi kasus: Kawasan Lereng Gunung Lawu, Kabupaten Karanganyar, Jawa Tengah. Jurnal Teknik ITS 6(1), 8790. DOI: 10.12962/j23373539.v6i1.22333

Pamungkas. Z. dan Sartohadi. J. (2017). Kajian Stabilitas Lereng Kawasan Longsor Di Sub-Das Bompon Kabupaten Magelang. Jurnal Bumi Indonesia, Vol 6 (2). file://C:/ Users/II/Downloads/728-1415-1-SM.pdf. Diakses pada tanggal 5 September 2018. 
Paimin, Sukresno, \& Pramono, I.B. (2009). Teknik Mitigasi Bajir dan Tanah Longsor, Balikpapan: Tropenboss International Indonesia Programme.

Paimin., Pramono. I. B., Purwanto, dan Indrawati. D. R. (2012). Sistem Perencanaan Pengelolaan Daerah Aliran Sungai. Bogor: Pusat Penelitian dan Pengembangan Konservasi dan Rehabilitasi.

Peraturan Menteri Pekerjaan Umum No. 22/PRT/M/2007 tentang Pedoman Penataan Ruang Kawasan Rawan Bencana Longsor. (2007). Direktorat Jenderal Penataan Ruang. Jakarta.

Pham. B. T., Bui. D. T., Prakash. I. dan Dholakia. M.B. 2017. Hybrid integration of Multilayer Perceptron Neural Networks and machine learning ensembles for landslide susceptibility assessment at Himalayan area (India) using GIS. Elsevier. Catena Journal 149, 52-63. https:// doi.org/10.1016/j.catena.2016.09.007

Purwanti. W., Prasetyo. Y., dan Yuwono. B. D. 2018. Analisis Dampak Perubahan Muka Tanah Akibat Bencana Tanah Longsor Terhadap kawasan Permukiman di Kabupaten Banjarnegara Menggunakan Metode DInSAR. Jurnal Geodesi Undip 7 (4), 254-263.

Pusat Vulkanologi dan Mitigasi Bencana Geologi. (2013). Gerakan Tanah. Bandung: Kementrian ESDM.

Pusat Vulkanologi dan Mitigasi Bencana Geologi. (2014). Hindari Bahaya Tanah Longsor. Bandung: Kementrian ESDM.

Pusat Vulkanologi dan Mitigasi Bencana Geologi. (2015). Prakiraan Wilayah Potensi Terjadi Gerakan Tanah/Tanah Longsor dan Banjir Bandang di Seluruh Indonesia. Bandung: Kementrerian ESDM.
Rosita. A., Aryanto. D., Noorainy. F., Slamet. M., dan Permadi. D. (2018). Daerah Rawan Bencana Geologi Gerakan Tanah dalam Arahan Kebijakan Mitigasi Kabupaten Ciamis. Jurnal Planologi 5(1): 886-896.

Sideng. U., Maru. R., Nyompa. S., Arfan. A., Malik. A., dan Abidin. M. R. (2018). Mapping and Zonation Level of Landslides Hazard and Risk Assessment: A Case Study of Enrekang Regency, South Sulawesi, Indonesia. Environment Asia 11(2) (2018) 149-163.

Susanti. P. D., Miardini. A. dan Harjadi. B. 2017. Analisis Kerentanan Tanah Longsor Sebagai Dasar Mitigasi Di Kabupaten Banjarnegara. Jurnal Penelitian Pengelolaan DAS 1 (1) April: 49-59.

Tian. Y., Chen. J. Xu. C., dan Lingling. S. (2017). Geometrical characteristics of earthquake-induced landslides and correlations with control factors: a case study of the 2013 Minxian, Gansu, China, Mw 5.9 event. Landslides. Dec 2017, Vol. 14 Issue 6, p1915, 13 p. DOI: 10.1007/ s10346-017-0835-6

Wen. F., Xin-Sheng. W., Yan-bo. C., dan Bin. Z. (2017). Landslide susceptibility assessment using the certainty factor and analytic hierarchy process. J. Mt. Sci. (2017) 14(5): 906-925. J. Mt. Sci. (2017) 14(5): 906-925 DOI: 10.1007/s11629-016-4068-2

Zhao. C. dan Lu. Z. (2018). Remote Sensing of Landslides-A Review. Remote Sens. 2018, 10, 279: 1-6. DOI:10.3390/ rs10020279.

Zhuang, Iqbal, Peng, Liu, T.M. (2014). Probability Prediction Model for Landslide Occurrences in Xi'an Shaanxi Province, China. Journal Mt, Science (11) (2): 349-359. DOI https://doi.org/10.1007/s11629-013-2809-z 